Серія "Психологія", випуск 69, 2020

\title{
ГЕНАЕРНА ПСИХОАОГІЯ
}

\section{Жіночність у психології: основні критерії та підходи}

\author{
Москаленко Вікторія Василівна \\ кандидат психологічних наук, дочент, дочент кафедри прикладної психологї \\ Харківський начіональний університет імені В.Н. Каразіна \\ майдан Свободи, 6, Харків, Україна, 61022 \\ e-mail:vvmoskalenko@karazin.ua \\ Пугач Анастасія Євгеніївна
} практичний психолог відділення амбулаторної психіатричної допомоги Центру психіатричної допомоги та професійного психологічного відбору Аержавної установи «Територіальне медичне об'єднання Міністерства внутрішніх справ Украӥни по Харківській області» e-mail:nastya.dafna@ukr.net

У статті розглянуто основні підходи до поняття жіночності в психологїі. Проаналізовано поняття «жіночність» у різних напрямках психологічної думки. Описано сучасне розуміння феномену жіночності. Обговорені концептуальні підходи щодо поняття «жіночність». Підкреслено роль ЗМІ у формуванні образу жіночності. Виявлені репрезентачіі жіночого образу у світовій культурі. Описані жіночі архетипи синдрому «емочійного холоду» в російських народних казках. Виділені критерї щодо структури поняття жіночності в психології.

Кнючові слова: жіночність; образ жінки; стереотипи жіночності; маскулінність та фемінінність; архетипи.

Актуальність проблеми. Особливого значення проблема наукового підходу до категорії жіночності набуває в сучасну епоху суспільних трансформацій, що стосуються не мише різних галузей соціальних віАносин, але й суттево впливають на психологію ї суб̆'єктів. Трансформація традиційних ролей спричинюе зміну соціальних ролей, ставлення до них, що має прояв у індивіАуально-психологічних вАастивостях сучасних жінок. Такі зміни потребують коригування моделей поведінки, ставлення АО суспільства, Ао інших, до себе.

У надзвичайно мобільному соціокультурному стані, сенс зрозумілих і непохитних, на перший погляд, понять зазнае кардинальних смислових трансформацій. Ця участь не оминула і концепцію жіночності.

Тому метою нашої статті є визначення поняття «жіночність», а також виділення основних критеріїв та концептуальних піАходів до феномену жіночності.

На сьогоднішній Аень не існує єАиного визначення жіночності. У науковій Аітературі Аля позначення жіночності як комплексу жіночих використовуеться термін фемінінність (або фемінність). АосліАження жіночих якостей вкАючені в гендерний напрямок і розглядають жінку в контексті статево-рольових відмінностей і віАносин. І.С. КАецина (2002) виАіляе три напрямки в історії розвитку гендерної проблематики: парадигма статевих відмінностей, парадигма унікальності жіночої психології, параАигма соціального конструювання гендеру.

Жіночність (також фемінність або фемінінність) - це модель поведінки і сукупність психічних якостей жіночого гендеру, таких як чутливість, ніжність, м'якість, жертовність, співчутливість та ін. Поняття жіночності задається соціальним, культурним, етнічним i віковим середовищем. Протилежністю жіночності є маскулінність (мужність) - чоловічий гендерний стереотип, що вк^ючає в себе такі риси, як сміливість, незалежність, впевненість в собі, емоційний контроль і раціональність.

Перший напрям АосліАжень віАноситься Ао феміністських теорій жіночої суб'єктивності Аругої й третьої хвилі фемінізму. НеодноріАність позицій і підходів усередині цього напряму вияв яяе складність і багатоаспектність жіночої суб̆'єктивності, хоча власне ії проблематизація є спільним завАанням усіх феміністських концепцій. Жіноча суб์'єктивність стає центральною проблемою фемінізму після роботи С. Ае Бовуар «Аруга стать» (1997), віА концепції жіночого як іншого стосовно чоловічого типу в культурі й віАходять різноманітні феміністські напрями.

Еволюційно-біологічна

(Г.М. Бреслав, В.П. Багрунов, В.А. Геодакян) та психоаналітична парадигми (3. ФрейА, К. Юнг) схожі у своїй Аумці, що жіночність обгрунтована вродженими особливостями психофізіологічних та анатомічних факторів.

Теорія жіночності Зігмунда Фройла (Мичерлих, 1996) грунтується на тому, що розвиток Аівчини, як майбутньої жінки, починається мише після усвіАомлення статевих віАмінностей.

У концепції К.Г. Юнга (Кочарян О.С, 2014) міститься розуміння маскулінності та фемінності через архетипічні образи Анімуса та Аніми. 
У рамках соціально-психологічної парадигми статеворольової іАентичності жінки, жіночність розглядається як закономірний витвір історіі та культури суспільства. Тобто, повністю підпорядкована закладеним у соціуму конструктам системи гендерних ролей, яку кожен засвоює 3 Аитинства.

При розгляданні питання жіночності теорія соціального навчання користується базовим принципом біхевіоризму - принципом обумовленої поведінки. ЗгіАно 3 іАеями преАставників цього напрямку (Ф. Парсонс, А.Бандура) розвиток статеворольової поведінки залежить віА двох аспектів. По-перше, важливу роль при формуванні поіедінки грає система покарань та заохочень. По-Аруге, спостерігаючи за своїми батьками, дитина насліАує ї особливості статеворольової поведінки та переносить їх у своє життя.

У противагу теоріі соціального навчання виступає теорія когнітивного розвитку. ЗгіАно 3 цим піАходом, Аитина $є$ активним учасником процесу пізнання. $\mathrm{Bi \Delta}$ неї вимагається самовизначити себе, як представника чоловічої або жіночої статі.

Репрезентацію жіночого образу у світовій культурі (Ажин Болен, 2009) можна розглялати 3 декількох піАстав. НаприкцаА:

- в аспекті рольових відносин у сім'і: Аочка, сестра, онучка, Аружина, наречена, мати;

- в морально-етичному аспекті за допомогою символічних образів: Свята Марія, Ева, Богоматір, вавилонська блудниця, праведниця, грішниця;

- у філософсько-символічному аспекті: Прекрасна принцеса, Софія Премудра, Мати Сира Земля, тощо;

- в аспекті суспільної презентації: студентка, Аомогосподарка, керівник, працівниця та інші .

Але все це лише певні образи, за Аопомогою яких можна спробувати глибше зрозуміти природу жіночності, проте не має чітко визначених критеріїв такого зрозумілого, проте водночас, неоднозначного поняття.

Ауже цікавим є виАілення критеріїв жіночності, спираючись на архетипи давньогрецьких богинь. Завдяки труду Ажин Болен «Богині в кожній жінці» (2009), жіночність описується через образи семі богинь, у яких яскраво проявцяється квінтесенція певних жіночих якостей та патернів поведінки. Тобто, аналізуючи образ богині ми маємо змогу побачити аспекти певних сучасних ролей жінки у соціумі.

Серед представлених богинь є більш традиційні, Аля розуміння жіночості, образи. НаприклаА, Гера - богиня-дружина, вірна своєму чоловікові, схильна до ревнощів та соціальнозалежної поведінки, яка дуже цінувалася у патріархальному суспільстві.
Вічно юна та тендітна богиня Персефона у взаємодії с сильним чоловічим образом поступово розкривається у справжню сміливу жінку. А богиня краси та Аюбові Афродіта $є$ справжнім архетипічним втіленням жіночої сексуальності та творчої свободи.

На противагу представленим стереотипним образам виникають більш зрозумілі нашому часу ролі. НаприклаА, справжня ікона фемінізму АртеміАа - смілива, рішуча, активна та незалежна богиня полювання. Вона усього Аомагається своїми силами. Їй не потрібна Аопомога віА чоловіків. Яскравий образ сучасної бізнес-леді. Чи інший приклаА - мудра та спокійна Афіна, жінкастратег, яка не поступається чоловікам ні в силі розуму, ні в силі характеру. Ауже нагадує сучасних жінок-вчених.

Прелставлені вище незалежні та сильні жіночі образи змогли актуалізуватися мише в останні сторіччя, тому зараз є Ауже яскраво проявленими у суспільстві. Вони з'яв яяються у книгах та фільмах, Аивляться на нас з екранів біг-бордів. ЗАається, це новий образ жінки, Ао якого усім необхіАно йти, віАкинувши свої звички та особистісні уяви.

Проте, як зазначала сама Ажин Болен (2009), А^я того, щоб жінка була зАоровою, успішною та щасливою, була сексуально приваблива та жила повним i творчим життям, Аюбила себе та оточуючих, в іiі житті повинні бути гармонійно виражені усі богині, і кожна у свій віАповіАний час.

Ще одна верся жіночих архетипів віА Черрі Гілкрайст (2007), які вона описує у книзі «Коло Аев'яти. Аспекти психіки сучасної жінки в Аев'яти архетипах». Аев'ять образів склаАаються 3 трьох тріад: Королев, Аам та Матерів. Закладається сутність трійчастої моделі буття, які можна описати як інтеграцію енергіi,, ii збереження та вивільнення у разі необхіАності. Черрі Гілкрайст виАіляє такі образи:

1) Королева Краси - ілеал краси,

2) Мати-Ткачиха - організуючий початок в жінці,

3) Берегиня Світла - втілення Милосердя, культ Аіви Марії у християнстві,

4) Королева Ночі - жінка, піАпорядкована інстинктивним поривам та первісній життєвій енергіi,

5) Велика Мати - втілення плодовитості, родючості, початку нового життя,

6) Господиня Вогнища - хранителька Аомашнього вогню і затишку,

7) Королева Землі - відображує цикл жіночої сексуальності, який поділяється на три фази: недоторкана, пробуджена та індивідуалізована сексуальність,

8) Справедлива Мати, яка символізує справедиивість та контроль (Богиня Феміла), 
9) Господиня Танцю - образ спонтанності, життсрадісності, свободи.

Королеви уособлюють жінок впевнених у собі та своій силі. Королеви мають певні володіння сектори впливу у особистості. Символом королеви у тілі є орган - серце.

Матері - це справжні творці гармонії та порядку. Вони створюють простір, наповнюють його, захищають, роблять комфортним. Аля себе вони беруть мише необхіАніше Аля подальшого зростання та розвитку, все інше віАкиАають. Їх особистий симво у у ті৯і - матка.

Аами - активні та енергійні. Вони красиві та граційні. 3Аатні перетворювати грубе и непривабливе на мегке і чарівне. Їх своєріАним символом є аура, енергетична оболонка, яка повністю оточує та пронизує тіло.

I знову ми можемо спостерегти певні закономірності. Кожен образ сам по собі $є$ яскравим та у певній мірі привабливим. Проте у ньому не вистачає повноти та різнобічності.

Існують АосліАження специфіки жіночої сексуальності (Смахтина, 2011), які висвітлюють Аосить цікаву картинку. Сексуальність проявАяється на різних рівнях: на фізичному, як певні риси зовнішності, які приваблюють чоловіків; на психологічному, у якості повних рис характеру; та, врешті-решт, у Ауховному, у якості певних творчих проявів, прийняття себе такою, яка є.

Ірина Щеглова (Кочарян тощо, 2015) в рамках психотерапевтичної методики театру архетипів запропонувала свій варіант рольових моделей, що випливають 3 жіночих архетипів. Вона виділяє наступні види і характеристики жіночих архетипів: Принцеса, войовниця, Королева, відьма (Чарівниця Фея) i Трікстер (Вертушок). Королевою стає принцеса, яка зуміла інтегрувати спокій войовниці і мудрість відьми, вказавши Вертушку їі місце.

О.С. Кочарян, Н.М. Терещенко та Т.С. Асланян (2015) описали жіночі архетипи синдрому «емоційного холоду» в російських народних казках: архетип «Спцяча царівна або Білосніжка», архетип «Царівни Жаби», архетип «Поганої матері», архетип «Царівни Несміяни», архетип «Маминя АОця», архетип «Папиня Аоця». НаприклаА, у поведінці сучасної жінки архетип "Сплячої царівни" проявляється в наступній поведінці. Жінка може зовні піАкреслювати власну красу, залучаючи чоловіків, при цьому залишаючись емоційно холодною. Вона може знецінювати чоловіка, приймаючи в спілкуванні з ним роль матері, старшої сестри або Аруга, при цьому, нарікаючи на те, що «чоловіки зараз стали мілкими (як гноми), i, мріючи про те, що Аесь існує іАеальний чоловік, який зможе зробити іiі щасливою. При появі поруч 3 такою жінкою чоловіка, який ії Аійсно приваблює, вона емоційно завмирає і очікує прояві ініціативи 3 його боку» (О.C Кочарян, Н.M. Терещенко \& Т.С. Асланян, 2015).

Без прийняття свого образу «Я» жінці складно бути привабливою, не Аивлячись на гарну зовнішність, чи інші критеріі. Коли жінка починає порівнювати себе 3 іншими, вона неодмінно знайде в собі якусь «значущу» ваАу, яка не співпадає з прийнятим у соціумі іАеалом. I стане заручником рекцами, брендів і маркетингу, які, усіма силами будуть переконувати ii недосконалості.

Значний вплив на сучасне розуміння жіночності мають засоби масової інформації. Саме вони поширюють у широкі маси певні актуальні соціальні та культурні стереотипи щодо варіацій образу жінки нашого часу. Можна виАілити три основних напрямки зображення жінки, які транслюються через рекламу, фільми та мультиплікацію.

ОАин із них - це привабливий образ ділової та успішної жінки, справжньої «бізнес-леді». Такий образ ввібрав у себе традиційно маскулінні якості, тому жінки, яких ми бачимо з екранів, є сильними, сміливими, соціально активними, незалежними віА чоловіків, на все мають свою Аумку. Крім того, така жінка приваблива фізично - мас атлетичну статуру, займається спортом та сліАкуе за своєю зовнішністю та зАоров'ям. Ао того ж вона інтелектуально розвинута, талановита, та успішна у своїй професії. Саме цей образ є Ауже популярним у соціумі. Проте, на Аумку І.В. Грошева (2000), основою цього образу є матентна ненависть Ао чоловіків, як Ао недосяжного компміментарного образу. I, ймовірний життевий сценарій, який пророкує нам цей образ - успішна у кар'єрі, але глибоко нещаслива у особистому житті, жінка.

Аругий образ Аемонструє нам набір стереотипно жіночих ролей: Аружини, Аомогосподарки, матері. Коло інтересів такої жінки безнадійно зімкнулося навколо хатніх справ, виховання Аітей та турботи про чоловіка. Їй властиві традиційно фемінні якості: залежність, вразливість, емоційність, пасивність. Сексуальність має місце Аише у негативному прояві. У більшості Аюдей цей образ викликає якщо не віАразу, то сум. Зображення саме такого образу матері (неохайної, стомленої та сумноі) у сучасній мультиплікації, викликає у маленьких Аівчат піАсвіАомий страх Ао материнства та заміжжя.

Третій популярний образ, на Аумку I.M. Тартаковської (2000), можна назвати «Косможінкою». У ньому жіночій образ має сенс об’екта споживання. Ця жінка може прояв ятися у Ауже різноманітних ролях: як матір, спортсменка, 
Аомогосподарка, студентка та інші. Проте головною іi ознакою $є$ спрямування на задоволення споживчих потреб різних товарів та послуг, які роблять ії привабливою та щасливою.

Чоловік у житті «космо-жінки» має свою предметну цінність. Тобто, сприймається як певна «річ», яка є показником успішності ії володарки. Чим більше матеріально забезпечений, фізично привабливий та «крутіший» чоловік - тим більше його товарна цінність в очах такої жінки. Такий партнер стає кращим елементом іi колекції «красивих, зручних та корисних речей», віА яких отримуєш задоволення, яке, все ж таки, має найвищу цінність. А Аля отримання такого трофею жінки у повну сику користуються своєю сексуальністю, як інструментом Аля маніпулювання. Аопомагає ій у цьому цілий арсенал косметики, вбрання та бьюті-послуг. Можна Аійти висновку, що цей образ жіночості володіє найяскравішим іміджем, проте позиціонує жінку мише як меркантильну споживчу особу, яка у відповіАь може надати мише красиву зовнішність, без яких би то ні було особистісних рис характеру.

Перелічені образи можуть впливати на статево рольову ідентичність жінки. Такі рольові моделі можуть закріпити у свідомості Аитини, що потрібно орієнтуватися на найбільш успішний образ, який преАставлений Аише сексуальною привабливістю. Серйозне заняття кар'єрою та високий інтелектуальний рівень дорівнює неуспішності в особистому житті. А материнство це взагалі крах життя.

Всі три образи мають мише фрагментарний характер. Ні один 3 них не показує цілого та гармонійного образа жіночності. I саме це, у майбутньому може призвести Ао виховання покоління 3 незрілою статево рольовою іАентичністю.

Висновки. Поняття "жіночність" на відміну віА наукового терміну фемінність має в українській мові емоційне забарвлення і часто розглялається як позитивна жіноча якість поряд 3 красою, порядністю i т. ін., 3 іншого боку, словом "жіночність" визначається цілий комплекс якостей жінки, таких як ніжність, м'якість, поступливість на противагу чоловічим якостям: сила, напористість тощо.

Визначаючи поняття «жіночністы), було проаналізовано такі концептуальні підходи: феміністський, еволюційно-біологічний, психоаналітичний, біхевіоріальний, гендерний. В історіі розвитку гендерної проблематики АосліАники виАіляють три головних парадигми. Це парадигма статевих віАмінностей, парадигма унікацьності жіночої психології та парадигма соціального конструювання гендеру.

Жіночність - це конкретні образи жінки, які описуються досліАниками у двох варіантах, по- перше, як гендерні репрезентації жіночих ролей, i по-Аруге, як рольові моделі, що випливають 3 жіночих архетипів.

Аослідження природи жіночності враховує три основних критерії. По-перше, це міфологічний критерій. Це складна система міфопоетичних значень, де співіснують приховані знаково-семіотичні піАсистеми “жіночності”. По-Аруге, це фольклорний критерій, яка містить у собі віАбиток архаїчних мотивів і міфологічних уявлень про жінку, на базі яких сформувалися такі жанри фольклору, як казки, ^егенАи, перекази про античних, біблійних або мокальних жіночих персонажів, що генетично та функціонально взаємоспоріАнені. Третій критерій - це науково-популярний, який грунтується на різних підходах до аналізу природи жіночності в соціальних мережах та засобах масової інформації.

\section{Список посилань}

Бовуар, де С. (1997). Второй пол. М.: Прогресс; СПб.: Алетейя.

Болен, А. Ш. (2007). Богини в каждой женщине. Новая психология женщины. Архетипв богинь. М.: София. https:/ / knigogid.ru/books/651542-bogini-v-kazhdoyzhenschine/toread

Гилкрайст, Ч. (2007). Круг девяти: аспекть психики современной женщины в девяти архетипах. М.: София. https://spblib.ru/en/catalog/-/books/11308623-thecircle-of-nine

Грошев, И. В. (2000). Гендерные образы рекламы. Вопросы психологии, 6, 38 - 45.

Клецина, И.С. (2002). Развитие гендерных исследований в психологии. Общественные науки и современность, $\quad 3, \quad 181-192$. http:/ /ecsocman.hse.ru/data/207/892/1217/17kLECINA.pdf

Кочарян, А.С., Жидко, М.Е., Терещенко, Н.Н. \& Фролова, Е.В. (2015). Полоролевая психология. Х.: ХНУ имени В. Н. Каразина. http://dspace.univer.kharkov.ua/handle/123456789/ 12506

Кочарян, А.С., Макаренко, А.А. \& Яровая, Н. А. (2014). Структурная организация симптомокомплекса маскулинности/ фемининности при разных уровнях психологического благополучия Аичности. Аичность, семья и общество: Вопрось педагогики и психологии, 5(40), 158-172. https://sibac.info/sites/default/files/archive/2014/2 014.05.19_pedagogika_i_psihologiya_pravka.pdf

Смахтіна, Н.О. (2011). Індивідуально-психологічні особливості жіночої сексуальності. (Аис. канА. психол. наук). Харківський національний університет імені В.Н. Каразіна, Харків. https://dspace.univer.kharkov.ua/handle/123456789/ 3037

Тартаковская, И.Н. (2000). «Сильная женщина плачет у окна». Гендерные репрезентации в советской и постсоветской массовой культуре. Аспекть сочиальной теории и современного общества. 
Кухтерин, С.Е., Согомонов, А.Ю. (РеА.). М.: Институт социологии РАН, 155-176. http://d1019822.idhost.kz/site03/social/s25.php

Micherlih, M., Rode-Dakser Kr. (1996). Psychoanalytische Diskurse über die Weiblichkeit von Freud bis Heute. Verlag Internationale Psychoanalyse, 7-30.

\section{References}

Bolen, D. Sh. (2007). Goddesses in every woman. New psychology of women. Archetypes of Goddesses. M: Sofia. https://knigogid.ru/books/651542-bogini-v-kazhdoyzhenschine/toread

Bovuar, de S. (1997) Second sex. M.: Progress; SPb.: Aleteyya.

Gilkrajst, Ch. (2007). The circle of nine: aspects of the psyche of a modern woman in nine archetypes. M.: Sofiya.

Groshev, I. V. (2000). Gender Images of Advertising. Voprosy psihologii, 6, 38 - 45.

Kletsina I.S. (2002). Development of gender research in psychology. Public Sciences and modernity, 3, 181-192. http://ecsocman.hse.ru/data/207/892/1217/17kLECINA.pdf

Kocharyan, A.S., Makarenko, A.A., Yarovaya, N.A. (2014). The structural organization of the masculinity / femininity symptom complex at different levels of psychological well-being of the individual. Lichnost, semya i obshchestvo: Voprosy pedagogiki i psibologii, 5, (40), 158-172.

https://sibac.info/sites/default/files/archive/2014/2 014.05.19_pedagogika_i_psihologiya_pravka.pdf

Kocharyan, A.S., Zhidko, M.E., Tereshchenko, N.N. (2015). Sex-role psychology. Kh: KhNU imeni V. N. Karazina.

Micherlih, M., Rode-Dakser Kr. (1996). Psychoanalytische Diskurse über die Weiblichkeit von Freud bis Heute. Verlag Internationale Psychoanalyse, 7-30.

Smahtina, N. O. (2011). Individual-psychological peculiarities of female sexuality. (Master's thesis). V.N. Karazin Kharkiv National University, Har'kov. https://dspace.univer.kharkov.ua/handle/123456789/ 3037

Tartakovskaya, I. N. (2000). "A strong woman is crying at the window." Gender Representations in Soviet and Post-Soviet Mass Culture. Aspekty socialnoy teorii $i$ sovremennogo obshchestva. Kukhterin, S.E., Sogomonov, A.Yu. (Ed.). M.: Institut sociologii RAN. http://d1019822.idhost.kz/site03/social/s25.php

Candidate of Psychological Science, Associate Professor, Associate Professor of the Applikd Psoria Moskalenko V.N. Karazin Kharkiv National University 6 Svobody Sq., Kharkiv, Ukraine, 61022

Anastasia Pugach Practical Psychologist of the Department of Outpatient Psychiatric Care of the Center for Psychiatric Care and Professional Psychological Selection of the State Institution "Territorial Medical Association of the Ministry of Internal Affairs of Ukeraine in the Kharkiv region" The article is devoted to the main approaches to the concept of femininity in psychology. The concept of "femininity" in various areas of psychological thought was analyzed. A modern understanding of the phenomenon of femininity was described. Conceptual approaches to the concept of "femininity" are discussed. The role of mass media in shaping the image of femininity is emphasized. Representations of the female image in world culture are revealed. Female archetypes of the "emotional cold" syndrome are described in Russian folk tales. Criteria for the structure of the concept of femininity in psychology are highlighted. Many different approaches to understanding femininity are analyzed. For example, the evolutionary-biological and psychoanalytic paradigms justify femininity by Innate anatomical and physiological factors. In the theory of cognitive development, a person, in the process of self-knowledge and self-actualization, introduces himself to representatives of a certain sex. Proponents of the theory of femininity refer to the latter the following characteristics: care, benevolence in relationships, high emotional sensitivity, compliance, developed intuition, credulity, ability to negotiate with the interlocutor, the ability to compromise, the direction to maintain psychological and emotional intimacy, inconsistency, emotional speech, talkativeness, smooth movements, openness, flexibility in relationships, attentiveness to socially accepted norms, naivety, vulnerability, low self-control, taking into account the opinions of others about themselves, unstable self-esteem, demonstrativeness, tendency to self-embellish, frivolity, superficiality in judgments, impulsiveness in decision-making. A systematic bolistic approach provides a model of criteria for femininity, which is convenient to represent in the form of a pyramid. It will be based on physical manifestations of femininity, inside - psychological, and at the top - spiritual. Each of these criteria is important, but it is necessary to invent an individual optimal manifestation of the physical, psychological and spiritual criteria of femininity. The media identifies three fragmentary inharmonious images of femininity (a single careerist, an unhappy housewife mother, and a sexual consumer of material goods).

Keywords: femininity; image of a woman; stereotypes of femininity; masculinity; archetypes.

Москаменко Виктория Васильевна кандидат психологических наук, дочент, дочент кафедры прикладной психологии Харьковский начиональныгй университет имени В.Н. Каразина nл. Свободьи,б, Харьков, Украина, 61022

Пугач Анастасия Евгеньевна

практический психолог отделения амбулаторной психиатрической помощи Центра психиатрической помочи и профессионального психологического отбора Государственного уиреждения «Территориальное медичинское объединение Министерства внутренних дел Украинвь по Харьковской области» В статье рассмотрены основные подходыг к понятию женственности в психологии. Проанализировано понатие «женственность» 6 разных направлениях психологической мысли. Описано современное понимание феномена женственности. Обсуждень конщептуальные подходы относительно понатия "женственность". Подчеркнута раль СМИ в формировании образа женственности. Выгявленьг репрезентачии женского образа в мировой культуре. Описаньг женские архетипьг синдрома «эмочионального холода» в русских народныгх сказках. Выгделены критерии относительно структуры понатия женственности в психологии.

Кнючевые снова: женственность; образ женщины; стереотипь женственности; маскулинность и фемининность; архетипьл. 